\title{
ANALISIS KOREKSI FISKAL UNTUK MENGHITUNG PPH BADAN PADA PT. EMPAT TUJUH ABADI JAYA
}

\author{
Mesias Ridel Tulandi ${ }^{1}$, Harijanto Sabijono ${ }^{2}$, Sonny Pangerapan ${ }^{3}$ \\ ${ }^{1,2,3}$ Jurusan Akuntansi, Fakultas Ekonomi dan Bisnis, Universitas Sam Ratulangi, Jl. Kampus Bahu, Manado, \\ 95115, Indonesia
}

E-mail : mesiastulandi19@gmail.com

\begin{abstract}
PT. Empat Tujuh Abadi Jaya is a company that is a taxpayer in the form of a body that has responsibility to calculate, deposit and report the tax payable that must be paid to the state based on self-assessment system that gives full trust to the taxpayer in reporting corporate tax. But there is a problem that will be faced in the payment of taxes. This is due to the fact that the financial statements in particular the income statements are different from the commercial profit referring to the Financial Accounting Standards while the fiscal profit refers to the applicable Taxation Law. This difference is simply in the presence of income and expenses recognized as income or expenses by the company but is not recognized by the tax and in the filling as the company does not pay attention to the fiscal correction in tax reporting. For that company must pay attention to fiscal correction / fiscal reconciliation so that the amount of corporate tax payable can be equal to tax. The purpose of this study is to determine the fiscal profit derived from the results of fiscal correction in commercial financial statements to determine the tax payable body. In this study, earnings obtained after the fiscal correction in the financial statements of Rp201,112,732.00 and profit before the fiscal correction of Rp181.510.720,00 for the calculation of corporate taxes using tarif 17 paragraph $2 a$ with tarif $25 \%$ Act No. 36 of 2008 Tax The income of the company must pay the tax before it is made Rp45.377.680,00 for the corporate tax rate less attention to the Article 31 E fare with $50 \%$ discount from the normal tarif of $25 \%$ gross turnover Rp4.8.000.000.000,00 or below and up to Rp50.000.000.000,00 billion got a discount. Gross circulation of PT. Empat Tujuh Abadi Jaya shall not exceed 4.8M amounting to $R p 4,669,400,000.00$, so the Company is permitted to use the rate of article $31 \mathrm{E}$.

Keywords: Tax due, Income Statement, Fiscal Correction.
\end{abstract}

\section{PENDAHULUAN}

Pajak menjadi kewajiban negara Indonesia, sehingga penagihannya dilakukan secara paksa. Sebagaimana menurut Undang-Undang No. 16 Tahun 2009 tentang Ketentuan Umum dan Tata Cara Perpajakan. Ketentuan Perpajakan sangatlah berkaitan dengan akuntansi sehingga timbul pemahaman tentang penyusunan laporan keuangan dan informasi finansial untuk kepentingan perpajakan. Koreksi fiskal/ rekonsiliasi fiskal adalah koreksi yang harus dilakukan oleh wajib pajak ketika menghitung besarnya Pajak Penghasilan (PPh) terutang pada akhir tahun, yang bertujuan untuk menyesuaikan besarnya laba menurut akuntansi yang disusun oleh perusahaan dengan laba menurut undang-undang perpajakan yang disusun oleh fiskus terkait dengan biaya-biaya yang diperkenankan dan yang tidak diperkenankan sebagai pengurangan penghasilan bruto.

PT. Empat Tujuh Abadi Jaya memberikan produk penjualan yang terdiri dari penjualan telur, penjualan ayam, penjualan pupuk. Perusahaan membuat laporan keuangan di tahun pertama berdasarkan standar akuntansi keuangan atas dasar inilah penulis ingin mengamati bagaimana perusahaan ini menyikapi perbedaan-perbedaan yang terjadi antara laba rugi komersial dan laba rugi fiskal. 


\section{TINJAUAN PUSTAKA}

\subsection{Konsep Akuntansi Pajak}

Konsep dasar akuntansi berlaku umum Laporan Keuangan Fiskal dan Komersial meliputi: Accrual basis: pengakuan transaksi saat terjadi transaksi, dilaporkan pada periode tersebut. Artinya pencatatan dilakukan pada saat terjadinya transaksi walaupun uang belum benar-benar diterima atau dikeluarkan. Going concern : mengasumsikan aktvitas perusahaan akan tetap berlangsung terus. Dimana pentingnya perusahaan melakukan perlunya likuidasi, penghentian perdagangan atau mencari perlindungan dari kreditur sesuai dengan Undangundang atau peraturan untuk menjaga supaya tetap going concern.

\subsubsection{Akuntansi Pajak}

Weygandt (2012) dalam Pontoh (2013:2) menjelaskan bahwa secara umum, akuntansi meliputi 3 (tiga) aktivitas dasar identifikasi, pencatatan, dan mengkomunikasikan peristiwa ekonomi dari sebuah organisasi kepada para pengguna yang berkepentingan. Pajak merupakan konstribusi rakyat yang bersifat memaksa karena dilindungi oleh Undang-undang rakyat tidak akan mendapat balas jasa secara langsung. Bagi perusahaan pajak merupakan sebuah tanggung jawab dan kewajiban yang harus dibayarkan kepada negara, atas kegiatan yang dilakukannya di dalam suatu negara.Akuntansi pajak adalah proses menyiapkan dan melaporkan perhitungan pajak terutang serta melakukan perencanaan pajak (Hery, 2014:4). Fungsi akuntansi pajak ini adalah untuk mengolah data kuantitatif yang akan digunakan untuk menyajikan laporan keuangan yang memuat perhitungan perpajakan.

\subsection{Tarif PPh Badan}

Variasi Tarif PPh Badan

1. Tarif pasal 17 ayat (1) huruf b (28\%) dan sekarang sudah tidak berlaku dan diperbaharui dengan.

2. Tarif pasal 17 ayat 2 a sejak tahun 2010 sebesar $25 \%$ (tarif normal yang berlaku sampai sekarang).

3. Tarif pasal 17 ayat $2 \mathrm{~b}$ adalah perseroan terbuka paling sedikit $40 \%$ dari keseluruhan saham yang disetor diperdagangkan di bursa efek Indonesia

Tarifnya 5\% lebih rendah dari tarif normal pasal 17 ayat 2a (tarif normal $25 \%$ ) ada pengurangan dari tarif normal 25\%-5\% =20\% diatur dalam PP 81 tahun 2007.

4. Tarif PPh badan pasal $31 \mathrm{E}$ yaitu omset sampai dengan Rp4.8M -50M akan mendapat potongan sebesar $50 \%$ dari tarif normal sebesar $25 \%$, jadi $(50 \% \mathrm{x}$ $25 \%)=12.5 \%$. Tarif pasal $31 \mathrm{E}$ merupakan tarif yang unik karena apabila wajib pajak orang pribadi atau badan memiliki omset 4,8 M s.d $50 \mathrm{M}$ akan mendapat fasilitas.
1. PKP dapat fasilitas : $4,8 \mathrm{M}$ $x$ PKP

\section{Peredaran Bruto}

5. Tarif PPh badan yang terutang untuk wajib pajak badan dengan peredaran bruto di atas 50 miliar rupiah setahun berlaku ketentuan umum berdasarkan UndangUndang No 36 Tahun 2008 (tanpa ada fasilitas pengurangan tarif). Besarnya PPh badan yang terutang mulai tahun pajak $2010=25 \%$ x PKP (penghasilan kena pajak).

\subsubsection{Perhitungan PPh Badan}

a. Tarif Normal 17 Ayat 2a

Contoh :

$$
\begin{array}{ll}
\text { Omset } & =\mathrm{Rp} 54.000 .000 .000,00 \\
\text { Penghasilan Kena Pajak (PKP) } & =\mathrm{Rp} 4.000 .000 .000,00 \\
& =25 \% \times 4.000 .000 .000,00(\mathrm{PKP}) \\
\mathrm{PPh} & =\mathrm{Rp} 1.000 .000 .000,00
\end{array}
$$

b. Tarif 17 ayat $2 b$ 


$$
\begin{aligned}
& \text { Contoh : } \\
& \begin{aligned}
\text { PKP } & =\text { Rp1.250.000.000,00 } \\
& =(25 \%-5 \%) \times \text { Rp } 1.250 .000 .000,00 \\
& =\text { Rp250.000.000,00 }
\end{aligned}
\end{aligned}
$$

Catatan omset sampai dengan $50 \mathrm{M}$ akan dikenakan tarif $\mathrm{PPh}$ pasal $31 \mathrm{E}$.

c. Contoh 1 Tarif $31 \mathrm{E}$

$$
\begin{aligned}
& \text { Omset } \quad=\text { Rp4.500.000.000,00 } \\
& \text { PKP } \quad=\text { Rp500.000.000,00 } \\
& \mathrm{PPh} \quad=50 \% \times 25 \% \times 500.000 .000,00 \\
& =\mathrm{Rp} 62.500 .000,00
\end{aligned}
$$

d. Contoh 2 (omset 4,8-50m)

$$
\begin{aligned}
& \text { Omset : Rp30.000.000.000,00 } \\
& \text { PKP : Rp3.000.000.000,00 } \\
& \text { PKP-fasilitas }=\frac{4,8 \mathrm{M}}{30 \mathrm{M}} \times 3.000 .000 .000,00=\mathrm{Rp} 480.000 .000,00
\end{aligned}
$$

\subsection{Konsep Koreksi Fiskal}

Koreksi fiskal merupakan suatu penyesuaian yang dilakukan sebelum menghitung pajak penghasilan bagi wajib pajak badan dan wajib pajak pribadi. Penyesuaiaan ini biasanya dilakukan karena adanya perbedaan pengakuan penghasilan antara akuntansi fiskal dengan akuntansi komersial.

\subsubsection{Koreksi Fiskal Positif}

Koreksi fiskal positif yaitu koreksi fiskal yang menyebabkan penambahan penghasilan kena pajak dan PPh terutang. Jenis koreksi fiskal positif terjadi antara lain sebagai akibat adanya:

a. Penggantian atau imbalan sehubungan dengan pekerjaaan atau jasa yang diberikan dalam bentuk natura dan kenikmatan, kecuali penyediaan makanan dan minuman bagi seluruh pegawai serta penggantian atau imbalan dalam bentuk natura dan kenikmatan didaerah tertentu dan yang berkaitan dengan pelaksanaan pekerjaan yang diatur dengan atau berdasarkan Peraturan Menteri Keuangan.

\subsubsection{Koreksi Fiskal Negatif}

Koreksi yang menyebabkan pengurangan penghasilan kena pajak dan $\mathrm{PPh}$ terutang. Jenis koreksi fiskal negatif antara lain sebagai akibat adanya:

1. Persediaan yang jumlahnya kurang jumlah berdasarkan metode penghitungan yang sudah ditetapkan dalam pasal 10 UU No. 36 tahun 2008 tentang PPh.

2. Penyusutan yang jumlahnya kurang jumlah berdasarkan metode penghitungan yang sudah ditetapkan.

\subsection{Penelitian terdahulu}

Beberapa penelitian terdahulu yang penulis jadikan sebagai bahan pertimbangan dalam melakukan penelitian di PT. Empat Tujuh Abadi Jaya. Penelitian yang dilakukan oleh Prang Buwono 2012, tentang Analisis Koreksi Fiskal atau Laporan keuangan pada CV. Reviana, menyatakan bahwa terdapat beberapa akun perbedaan pengakuan penghasilan dan biaya setelah di rekonsiliasi. Pada penelitian yang dilakukan oleh Rismawani A Tety tahun 2016, tentang Analisis Koreksi Fiskal Atas Laporan Keuangan Komersial dalam penentuan Pajak Penghasilan pada PT. Gajah Mada Indrasehati Semarang, menyatakan bahwa terdapat laba yang diperoleh berdasarkan laporan keuangan komersial yang berbeda dengan laporan keuangan fiskal, serta terdapat kurang bayar pajak penghasilan perusahaan. Pada penelitian yang dilakukan oleh Nur Akmalia tahun 2014, tentang Penyusunan Koreksi Fiskal Terhadap Laporan Keuangan komersial menurut undang-undang pajak penghasilan No.36 tahun 2008 pada Koperasi unit desa Karya Sawit, menunjukkan ada perbedaan pengakuan pendapatan dan biaya yang dilakukan Koperasi unit desa Karya Sawit. 


\section{METODE PENELITIAN}

\subsection{Jenis Penelitian}

Penelitian ini termasuk pada jenis penelitian kualitatif. Sugiyono (2014:5) adalah metode penelitian yang digunakan untuk meneliti objek yang alamiah dimana peneliti sebagai instrumen kunci. Deskriptif adalah suatu prosedur pemecahan masalah yang diselidiki dengan menggambarkan keadaan subjek atau objek dalam penelitian dapat berupa orang, lembaga, masyarakat dan yang lainnya yang pada saat sekarang berdasarkan fakta-fakta yang tampak atau apa adanya, dalam meneliti status kelompok manusia, suatu objek, suatu set kondisi, suatu sistem pemikiran, ataupun suatu kelas peristiwa pada masa sekarang. Jenis penelitian dilakukan langsung ke sumber data, pengumpulan data menggunakan instrument penelitian, dan data yang terkumpul berupa visi dan misi perusahaan, struktur organisasi, dan informasi laporan keuangan bagaimana perusahaan menyusun laporan keuangan dengan memperhatikan koreksi fiskal yang di lakukan di PT. Empat Tujuh Abadi Jaya.

\subsection{Waktu dan Tempat Penelitian}

Penelitian dilakukan di PT. Empat Tujuh Abadi Jaya, yang merupakan perusahaan yang bergerak di bidang peternakan ayam bertelur. Dan berlokasi di JL. R.W. Mongisidi Lingkungan 1 Kelurahan Malalayang Satu, Kecamatan Malalayang, kota Manado. Sulawesi Utara. Waktu penelitian dimulai dari bulan Februari 2018 sampai April 2018.

\subsection{Metode Analisis}

Metode analisis yang digunakan dalam penulisan skripsi ini adalah metode deskriptif kualitatif Proses analisis merupakan proses awal dalam tahap perencanaan penyelesaian suatu masalah. (Sugiyono, 2014:14). Untuk melakukan proses analisis penelitian, penulis di dalam penelitian ini, penulis akan mempelajari laporan keuangan yang diperoleh dari perusahaan.

\section{HASIL ANALISIS DAN PEMBAHASAN}

\subsection{Hasil analisis}

\subsubsection{Neraca PT. Empat Tujuh Abadi Jaya}

\begin{tabular}{|c|c|c|c|c|c|c|}
\hline \multicolumn{7}{|c|}{ PT. EMPAT TUJUH ABADI JAYA } \\
\hline \multicolumn{7}{|c|}{ NERACA } \\
\hline \multicolumn{7}{|c|}{ PER 31 DESEMBER 2017} \\
\hline & & & & & & \\
\hline & & & & & & (dalam Rp.) \\
\hline AKTIVA & & & & PASSIVA & & \\
\hline & & & & KFWAUIAN & & \\
\hline Kas & $30,000,000$ & & & \begin{tabular}{|l} 
Kewaiiban Lanca \\
\end{tabular} & & \\
\hline Piutang Usaha & $52,500,000$ & & & Hutang Bank & $700,000,000$ & \\
\hline Persediaan Telur & $19,200,000$ & & & Hutang dagang & $399,000,000$ & \\
\hline Persediaan Ayam & $242,000,000$ & & & Hutang lain-lain & $60,680,000$ & \\
\hline Persediaan Pakan & $507,080,000$ & & & & & \\
\hline Persediaan Obat/Vitamin & $89,200,000$ & & & Total Kewajiban & & $1,159,680,000$ \\
\hline Total Aktiva Lancar & & $939,980,000$ & & & & \\
\hline & & & & & & \\
\hline Aktiva Tetap & & & & Modal/Equity & & \\
\hline Tanah & $500,000,000$ & & & Modal & $1,000,000,000$ & \\
\hline Bangunan & $312,000,000$ & & & Laba ditahan & $181,510,720$ & \\
\hline Akumulasi penyusutan bangunan & $(31,200,000)$ & & & Total Modal & & $1,181,510,720$ \\
\hline Kendaraan A & $119,000,000$ & & & & & \\
\hline Akumulasi penyusutan kendaraan A & $(17,000,000)$ & & & & & \\
\hline Kendaraan B & $129,000,000$ & & & & & \\
\hline Akumulasi penyusutan kendaraan B & $(18,428,568)$ & & & & & \\
\hline Kendaraan C & $142,000,000$ & & & & & \\
\hline Akumulasi penyusutan kendaraan C & $(20,285,712)$ & & & & & \\
\hline Kandang ayam & $327,000,000$ & & & & & \\
\hline Akumulasi penyusutan kandang ayam & $(40,875,000)$ & & & & & \\
\hline Total Aktiva Tetap & & $1,401,210,720$ & & & & \\
\hline Total Aktiva & & $2,341,190,720$ & & Total Passiva & & $2,341,190,720$ \\
\hline
\end{tabular}

Sumber : data dari PT. Empat Tujuh Abadi Jaya 
Dari Neraca yang ada ini, dapat kita lihat bahwa PT. Empat Tujuh Abadi Jaya memiliki total aktiva lancar sebesar Rp939.980.000,00 yang terdiri dari Kas, Piutang Usaha, Persediaan telur, Persediaan ayam, Persediaan pakan, Persediaan Obat/vitamin. Total Aktiva tetap sebesar Rp1.401.190.720,00 dari Tanah Rp500.000.000,00 Bangunan Rp312.000.000,00 dikurangi akumulasi penyusutan bangunan Rp31.200.000,00 Kendaraan A Rp119.000.000,00 dikurangi akumulasi penyusutan kendaraan A Rp17.000.000,00 Kendaraan B Rp129,000.000,00 dikurangi akumulasi penyusutan kendaraan B Rp18.428.568,00 Kendaraan C Rp142.000.000,00 dikurangi akumulasi penyusutan kendaraan C Rp20.285.712,00 Kandang ayam Rp327.000.000,00 dikurangi akumulasi penyusutan kandang ayam Rp40.875.000,00

Dilihat dari sisi kewajiban, terdapat total hutang sebesar Rp1.017.680.000,00 didapat dari Hutang bank sebesar Rp600.000.000,00 Hutang dagang sebesar Rp357.000.000,00 Hutang lain-lain sebesar Rp60.680.000,00 Jumlah total modal adalah sebesar Rp1.473.510.720,00 didapat dari Modal sebesar Rp1.292.000.000,00 Laba ditahan Rp181.510.720,00

Dalam koreksi fiskal pada neraca hanya akan mengubah hasil hutang pajak pada suatu perusahaan. Koreksi fiskal itu sendiri lebih di tekankan pada laporan rugi-laba perusahaan.

\subsubsection{Laba rugi PT. Empat Tujuh Abadi Jaya}

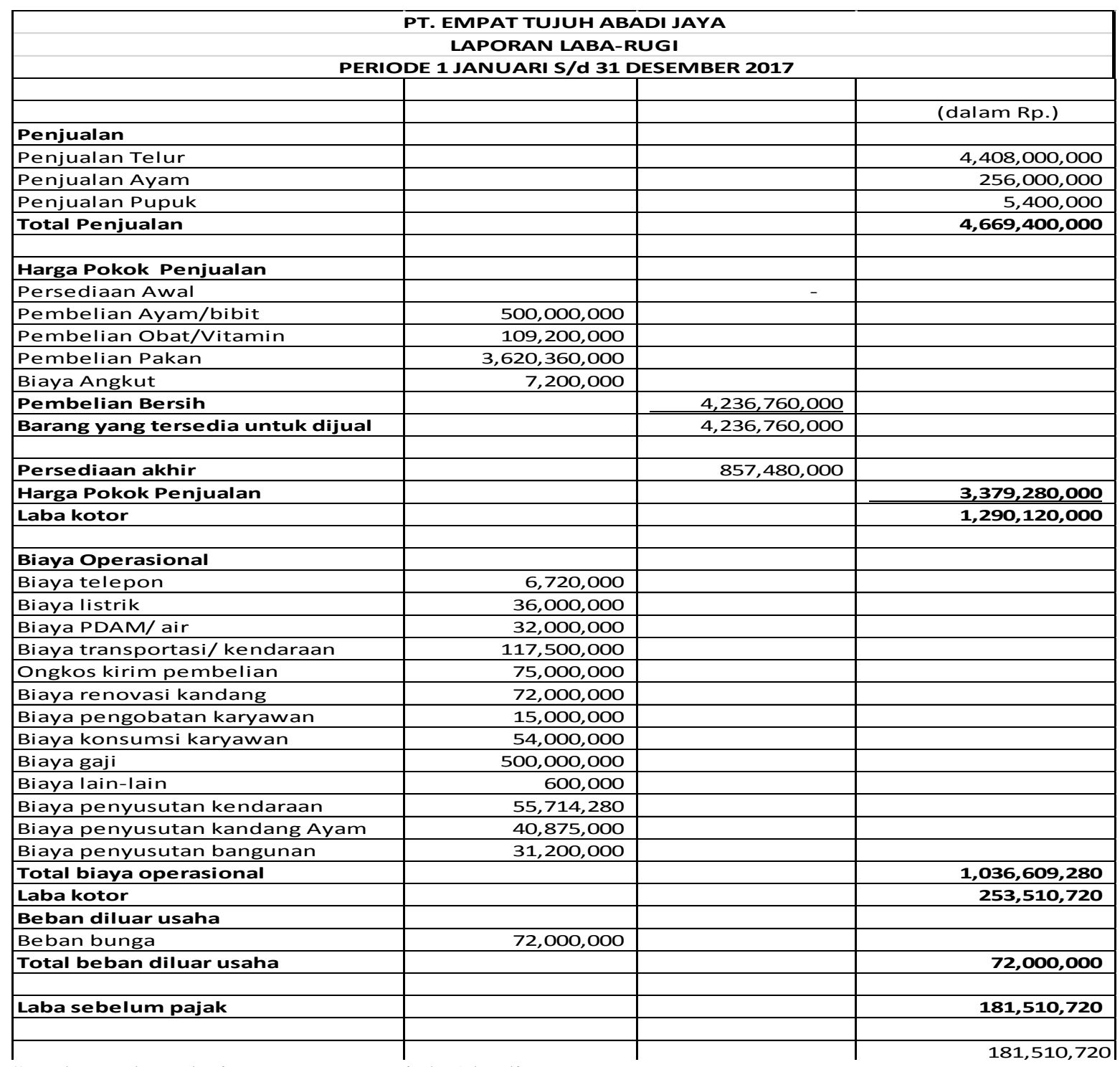

Sumber : data dari PT. Empat Tujuh Abadi Jaya 
Dari laporan laba rugi PT. Empat Tujuh Abadi Jaya dapat dilihat laba yang diperoleh oleh perusahaan selama satu periode akuntansi. Dengan jumlah laba sebelum pajak Rp181.510.720.00.

\subsection{Pembahasan}

Dalam laba-rugi perusahaan yang harus dilakukan penyesuaian.

1. Di antaranya biaya konsumsi karyawan. Biaya konsumsi karyawan merupakan biaya yang sudah dilakukan perusahaan sebagai biaya yang mengurangi penghasilan yang termasuk dalam biaya operasional perusahaan, akan tetapi menurut perpajakan bukan merupakan biaya yang diperkenankan sebagai pengurang penghasilan, dari biaya konsumsi karyawan sebesar Rp54.000.000,00 akun biaya konsumsi karyawan dan harus dikoreksi positif sesuai dengan peraturan perpajakan yang berlaku dan menurut Pasal 9 ayat (1) huruf e, UU Nomor 36 tahun 2008, bahwa beban penggantian atau imbalan sehubungan dengan pekerjaan atau jasa yang diberikan dalam bentuk natura dan kenikmatan, kecuali penyediaan makanan dan minuman bagi seluruh karyawan serta penggantian atau imbalan dalam bentuk natura dan kenikmatan didaerah tertentu yang berkaitan dengan pelaksanaan pekerjaan yang diatur dengan atau berdasarkan Peraturan Menteri Keuangan, maka untuk biaya konsumsi karyawan tidak dapat diakui sebagai beban yang akan mengurangi penghasilan (non deductible expense). Jadi, dalam rekonsiliasi fiskal akun biaya/beban konsumsi karyawan dalam laporan laba-rugi komersial tersebut harus dikoreksi positif sesuai dengan jumlah biaya konsumsi sebesar Rp54.000.000,00

2. Biaya pengobatan karyawan merupakan biaya operasional perusahaan di mana perusahaan menganggap biaya pengobatan karyawan merupakan biaya pengurang atau beban pengurang penghasilan yang diberikan kepada sebagian karyawan perusahaan. Menurut perpajakan akun biaya pengobatan karyawan bukan merupakan biaya yang dapat dikurangkan sebagai beban pengurang penghasilan (non deductible expense), sesuai dengan peraturan perpajakan yang berlaku menurut pasal 9 ayat (1), UU Nomor 36 Tahun 2008, bahwa beban penggantian atau imbalan sehubungan dengan pekerjaan atau jasa yang diberikan dalam bentuk natura dan kenikmatan, kecuali penyediaan makanan dan minuman bagi seluruh karyawan serta penggantian atau imbalan dalam bentuk natura dan kenikmatan didaerah tertentu yang berkaitan dengan pelaksanaan pekerjaan yang diatur dengan atau berdasarkan Peraturan Menteri Keuangan, maka untuk biaya pengobatan karyawan tidak dapat diakui sebagai beban yang akan mengurangi penghasilan (non deductible expense). Karena biaya pengobatan karyawan hanya diberikan kepada sebagian karyawan sesuai dengan ketentuan perpajakan dalam pasal 9 ayat 1, biaya pengobatan karyawan diberikan untuk seluruh karyawan, jadi biaya pengobatan karyawan tidak bisa dibebankan sebagai beban pengurang penghasilan (non deductible expense). Akun biaya pengobatan harus dikoreksi positif sebesar Rp 15.000.000,00

3. Biaya penyusutan menurut perusahaan

Dalam menentukan besarnya beban penyusutan, PT. Empat Tujuh Abadi Jaya menggunakan metode garis lurus yaitu dengan menggunakan masa manfaat/umur ekonomis dikali dua belas bulan, setelah itu dibagi harga perolehan. Pengelompokkan aktiva tetap perusahaan mengelompokkan ke dalam kelompok II aktiva berwujud bukan bangunan. 


\section{Kelompok II}

Kendaraan A

\begin{tabular}{|c|c|c|c|c|}
\hline \multirow{2}{*}{ No } & Aktiva & Harga perolehan & \multicolumn{2}{|c|}{ Secara Komersial } \\
\cline { 4 - 5 } & & & Akm Penyusutan & Nilai buku \\
\hline 1 & Kendaraan A & Rp 119.000.000 & Rp 1.416.666 & Rp 117.583.334 \\
\hline
\end{tabular}

Ket : Kendaraan A masa manfaat $=7$ tahun, harga perolehan : Rp 119.000.000

$=\operatorname{Rp} 119.000 .000:(7 \times 12)$

$=\operatorname{Rp} 119.000 .000:(84$ bulan $)$

$=$ Rp 1.416.666. per bulan, per tahun $=\operatorname{Rp} 1.416 .666 \times 12$ bulan

$=\mathrm{Rp}$ 17.000.000 per tahun

\section{Kendaraan B}

\begin{tabular}{|c|c|c|c|c|}
\hline No & Aktiva & Harga perolehan & \multicolumn{2}{|c|}{ Secara Komersial } \\
\cline { 4 - 5 } & & & Akm Penyusutan & Nilai buku \\
\hline 1 & Kendaraan B & Rp 129.000.000 & Rp 1.535.714 & Rp 127.464.286 \\
\hline
\end{tabular}

Ket : Kendaraan B, masa manfaat : 7 tahun, dengan harga perolehan $=$ Rp 129.000.000

$=\operatorname{Rp} 129.000 .000:(7 \times 12)$

$=\operatorname{Rp} 129.000 .000:(84$ bulan $)$

$=\mathrm{Rp}$ 1.535.714 per bulan penyusutan, per tahun $=\mathrm{Rp} 1.535 .714 \times 12$ bulan

$=\mathrm{Rp}$ 18.428.568 per tahun

\section{Kendaraan C}

\begin{tabular}{|c|c|c|c|c|}
\hline \multirow{2}{*}{ No } & Aktiva & Harga perolehan & \multicolumn{2}{|c|}{ Secara Komersial } \\
\cline { 4 - 5 } & & & Akm Penyusutan & Nilai buku \\
\hline 1 & Kendaraan C & Rp 142.000.000 & Rp 1.690.476 & Rp 140.309.524 \\
\hline
\end{tabular}

Ket: Kendaraan C, masa manfaat 7 tahun, harga perolehan = Rp 142.000.000

$=\operatorname{Rp} 142.000 .000$ (7x12 bulan)

$=\operatorname{Rp} 142.000 .000$ (84 bulan)

$=\operatorname{Rp} \quad \mathbf{1 . 5 3 5 . 7 1 4}$ per bulan penyusutan,

$=\mathrm{Rp} 1.535 .714$ x12 bulan

$=\mathbf{R P}$ 20.285.712 per tahun penyusutan

Biaya penyusutan menurut perpajakan

Sesuai dengan Undang-undang Perpajakan No. 36 tahun 2008 yang berlaku saat ini, beban penyusutan dihitung berdasarkan pengelompokkan jenis aktiva tetap. Dalam hal ini, kendaraan $\mathrm{A}$, kendaraan $\mathrm{B}$, dan kendaraan $\mathrm{C}$ perusahaan dikelompokkan kedalam jenis aktiva tetap berwujud kelompok II, dengan masa manfaat 8 tahun jadi besarnya beban penyusutan dari aktiva adalah:

\section{Kelompok II}

Kendaraan A

\begin{tabular}{|c|c|c|c|c|}
\hline \multirow{2}{*}{ No } & Aktiva & Harga perolehan & \multicolumn{2}{|c|}{ Secara Komersial } \\
\cline { 3 - 5 } & & & Akm Penyusutan & Nilai buku \\
\hline 1 & Kendaraan A & Rp 119.000.000 & Rp 1. 239.583 & Rp 117.760.417 \\
\hline
\end{tabular}

Ket : Kendaraan A masa manfaat $=8$ tahun, harga perolehan $: \operatorname{Rp} 119.000 .000$

$=\operatorname{Rp} 119.000 .000:(8 \times 12)$

$=\operatorname{Rp} 119.000 .000:(96$ bulan $)$

$=$ Rp 1.239.583. per bulan, per tahun $=R p 1.239 .583 \times 12$ bulan

$=\mathrm{Rp}$ 15.522.996 per tahun

\section{Kendaraan B}




\begin{tabular}{|c|c|c|c|c|}
\hline No & Aktiva & Harga perolehan & \multicolumn{2}{|c|}{ Secara Komersial } \\
\cline { 4 - 5 } & & & Akm Penyusutan & Nilai buku \\
\hline 1 & Kendaraan B & Rp 129.000.000 & Rp 1.343.750 & Rp 127.656.250 \\
\hline
\end{tabular}

Ket : Kendaraan B, masa manfaat : 8 tahun, dengan harga perolehan = Rp 129.000.000

$=\operatorname{Rp} 129.000 .000:(8 \times 12)$

$=\operatorname{Rp} 129.000 .000:$ (96 bulan)

$=\mathrm{Rp}$ 1.343.750 per bulan penyusutan, per tahun $=\mathrm{Rp} 1.343 .750 \times 12$ bulan

$=\operatorname{Rp}$ 16.125.000 per tahun

Kendaraan C

\begin{tabular}{|c|c|c|c|c|}
\hline \multirow{2}{*}{ No } & Aktiva & Harga perolehan & \multicolumn{2}{|c|}{ Secara Komersial } \\
\cline { 4 - 5 } & & & Akm Penyusutan & Nilai buku \\
\hline 1 & Kendaraan C & Rp 142.000.000 & Rp 1. 479.166 & Rp 140.520.834 \\
\hline
\end{tabular}

Ket: Kendaraan C, masa manfaat 8 tahun, harga perolehan $=\mathrm{Rp} 142.000 .000$

$=\operatorname{Rp} 142.000 .000:(8 \times 12$ bulan $)$

$=\operatorname{Rp} 142.000 .000:(96$ bulan)

$=$ Rp 1.479.166 per bulan penyusutan,

$=\operatorname{Rp} 1.535 .714 \times 12$ bulan

$=$ RP 17.749.992 per tahun penyusutan

Tabel 4.4

Perbandingan beban penyusutan menurut akuntansi komersial dan akuntansi perpajakan

\begin{tabular}{|c|c|c|c|c|}
\hline No & Jenis Aktiva Tetap & $\begin{array}{c}\text { Penyusutan } \\
\text { Komersial }\end{array}$ & $\begin{array}{c}\text { Penyusutan } \\
\text { Fiskal }\end{array}$ & Selisiih \\
\hline 1 & Kendaraan A & 17.000 .000 & 15.522 .996 & $(1.477 .004)$ \\
\hline 2 & Kendaraan B & 18.428 .568 & 16.125 .000 & $(2.303 .568)$ \\
\hline 3 & Kendaraan C & 20.285 .712 & 17.749 .992 & $(2.535 .720)$ \\
\hline & Total & 55.714 .280 & 49.397 .988 & $(6.316 .292)$ \\
\hline
\end{tabular}

Dari tabel 4.4 di atas, dapat diketahui bahwa terdapat selisih negatif, di mana beban penyusutan aktiva tetap (baik penyusutan kendaraan A, kendaraan B maupun kendaraan C) yang diakui oleh perusahaan PT. Empat Tujuh Abadi Jaya lebih besar dari pada beban penyusutan berdasarkan peraturan perpajakan, sehingga harus dikoreksi negatif.

Laba Bersih Sebelum Pajak Penghasilan

Menurut Akuntansi

$$
=\text { Rp181.510.720,00 }
$$

Koreksi Fiskal

- Fiskal Positif

a. Biaya Konsumsi Karyawan $=\mathrm{Rp} 54.000 .000,00$

b. Biaya Pengobatan Karyawan $=$ Rp15.000.000,00

- Fiskal Negatif

a. Biaya Penyusutan Kendaraan $=\mathrm{Rp} 49.397 .988,00$

Jumlah Koreksi Fiskal $=$ Rp19.602.012,00

Laba Sebelum Pajak Penghasilan Menurut Fiskal (Laba Fiskal)

\subsubsection{Perhitungan PPh badan}

$$
\text { = Rp201.112.732,00 }
$$

- Peredaran Usaha Bruto

- Jumlah Peredaran Bruto Pada Tahun 2017:

- Penjualan Telur Ayam

Rp4.408.000.000,00 


$\begin{array}{ll}\text { - } \quad \text { Penjualan Ayam } & \text { Rp256.000.000,00 } \\ \text { - Penjualan Pupuk } & \frac{\text { Rp5.400.000,00 }}{\text { Jumlah }} \\ \text { Jp4,669,400,000,00 }\end{array}$

Dalam perhitungan PPh Badan PT. Empat Tujuh Abadi Jaya sesuai data spt 1771 Tahunan Badan tahun 2017, diketahui perusahaan menggunakan tarif normal dalam perhitungan $\mathrm{PPh}$ terutang badan, yaitu tarif 17 ayat $2 \mathrm{~b}$ sebesar $25 \%$ yang diberlakukan sejak tahun 2010.

Diketahui :

Omset/ peredaran bruto

PKP/ Penghasilan Kena Pajak

PPh Terutang

$$
\begin{aligned}
& =\mathrm{Rp} 4.669 .400 .000,00 \\
& =\mathrm{Rp} 181.510 .720,00 \\
& =25 \% \times 181.510 .720,00 \\
& =\mathrm{Rp} 45.377 .680,00
\end{aligned}
$$

Dalam catatan atas laporan keuangan di atas peredaran bruto PT. Empat Tujuh Abadi Jaya Tahun 2017 sebesar Rp4.669.400.000,00 yang mana peredaran bruto perusahaan tersebut diperkenankan menggunakan tarif $\mathrm{PPh}$ pasal $31 \mathrm{E}$ karena peredaran bruto perusahaan tidak melebihi Rp4.8M, dengan perhitungan setelah diperoleh laba fiskal dengan melakukan koreksi fiskal menurut perpajakan sebagai berikut :

Peredaran Bruto/Omset

PKP (Penghasilan kena pajak)

PPH Terutang

$$
\begin{aligned}
& =\mathrm{Rp} 4.669 .400 .000,00 \\
& =\mathrm{Rp} 201.112 .732,00 \\
& =50 \% \times 25 \% \text { x 201.112.732,00 } \\
& =\mathrm{Rp} 25.139 .000,00
\end{aligned}
$$

Dalam pembayaran pajak perusahaan yang menggunakan tarif 17 ayat $2 \mathrm{~b}$ dan tidak menggunakan tarif pasal $31 \mathrm{E}$, yang berdasarkan Undang-undang No 36 Tahun 2008. Akan berbeda, tarif 17 ayat $2 \mathrm{~b}$ diperoleh PPh Terutang Badan sebesar Rp45.377.680,00 dan dengan menggunakan tarif pasal 31 E diperoleh PPh terutang Badan sebesar Rp25.139.000,00.

Sesuai peraturan perpajakan, telah dilakukan beberapa koreksi fiskal yang meningkatkan laba kena pajak PT. Empat Tujuh Abadi Jaya. Laba bersih dalam laporan laba rugi komersial adalah Rp181.510.720,00 sedangkan laba bersih setelah dikoreksi fiskal adalah sebesar Rp201.112.732,00 dan hal itu tentu saja mempengaruhi jumlah pajak yang harus dibayar. Sebelum dilakukan koreksi fiskal, PT. Empat Tujuh Abadi Jaya harus membayar pajak sebesar Rp45.377.680,00 setelah dilakukan koreksi fiskal dan dengan menggunakan tarif pasal 31 E, PT.Empat Tujuh Abadi Jaya harus membayar pajak sebesar Rp25.139.000,00 hal ini telah sesuai dengan Undang-undang perpajakan yang berlaku.

\section{KESIMPULAN DAN SARAN}

\subsection{Kesimpulan}

Berdasarkan hasil penelitian dan pembahasan yang telah dilakukan pada PT.Empat Tujuh Abadi Jaya, maka dapat ditarik kesimpulan sebagai berikut.

1. Koreksi fiskal sangat perlu dilakukan karena dapat membantu dalam rangka perhitungan pajak penghasilan badan dari PT. Empat Tujuh Abadi Jaya, sehingga pihak PT. Empat Tujuh Abadi Jaya dapat melakukan pembayaran pajak secara benar sesuai dengan peraturan perpajakan yang berlaku.

2. Hasil penelitian ini laba sebelum di koreksi fiskal sebesar Rp181.510.720,00 setelah di koreksi fiskal positif dan koreksi fiskal negatif laba sebesar Rp201.112.732,00 selisih sebesar Rp19.602.012,00.

\subsection{Saran}

Berdasarkan pembahasan dan kesimpulan yang telah diuraikan terdapat beberapa saran yang dapat diberikan untuk PT. Empat Tujuh Abadi Jaya yaitu, sebagi berikut,

1. PT. Empat Tujuh Abadi Jaya harus membuat koreksi fiskal dalam membuat laporan labarugi perusahaan dan memperhatikan koreksi fiskal positif dan koreksi fiskal negatif dalam 
pengisian SPT Tahunan 1771. Sehingga perusahaan dapat selalu melakukan pembayaran pajak penghasilan yang benar berdasarkan dengan laba kena pajak menurut fiskal dan sesuai dengan peraturan perpajakan yang berlaku.

2. Perusahaan harus lebih memperhatikan aspek-aspek yang harus dikoreksi fiskal sesuai dengan peraturan perpajakan yang berlaku atas pengakuan pendapatan-pendapatan dan beban-beban, agar supaya dapat dilakukan penyesuaian fiskal yang tepat sesuai ketentuan perpajakan.

3. PT. Empat Tujuh Abadi Jaya sebaiknya memperhatikan penghitungan biaya penyusutan dengan memperhatikan pengelompokkan harta berwujud serta masa manfaat menurut perpajakan. Sehingga tidak mengalami kekeliruan dalam perhitungan biaya penyusutan.

4. PT. Empat Tujuh Abadi Jaya sebaiknya menggunakan tarif pasal 31 E berdasarkan Undang- undang Nomor 36 Tahun 2008 dalam perhitungan PPh terutang badan sesuai dengan peredaran bruto, perusahaan mendapat potongan $50 \%$ dari tarif normal $25 \%$ adalah sebesar $12.5 \%$, sehingga $\mathrm{PPh}$ terutang badan menjadi lebih kecil dari perhitungan badan sebelumnya yang menggunakan tarif 17 ayat $2 \mathrm{~b}$. Dengan demikian dalam pengisian dan pelaporan pajak badan dalam SPT Tahunan Badan perusahaan dapat melaporkan pajak berdasarkan tarif pasal $31 \mathrm{E}$.

\section{DAFTAR PUSTAKA}

Akmalia, Nur. 2014. Penyusunan Koreksi Fiskal Terhadap Laporan Keuangan Komersial Menurut Undang-undang Pajak Penghasilan No.36 Tahun 2008 pada Koperasi Unit Desa Karya Sawit. Skripsi. Universitas Islam Negeri Sultan Syarif Kasim Riau. Pekanbaru.

Buwono, Prang. 2012. Analisis Koreksi Fiskal atas Laporan Keuangan Komersial Pada CV. Reviana. Skripsi. Universitas Gunadarma. Jakarta.

Hery. 2014. Akuntansi Perpajakan. PT.Grasido. Jakarta.

Pontoh, Winston. 2013. Akuntansi Konsep dan Aplikasi”. Buku 1. Halaman Moeka Publishing. Jakarta Barat.

Rismawani, A. Tety. 2016. Analisis Koreksi Fiskal Atas Laporan Keuangan Komersial dalam penentuan Pajak Penghasilan pada PT. Gajah Mada Indrasehati Semarang. Skripsi. Universitas 17 Agustus 1945. Semarang.

Sugiyono. 2014. Metode Penelitian Kuantitatif, Kualitatif. Alfabeta. Jakarta. 